\title{
The Investigation of Quality Changes in Marinades Obtained from Frozen African Catfish (Clarias gariepinus, B., 1822)
}

\author{
${ }^{1}$ Gulderen Kurt Kaya, ${ }^{2}$ Buket Busra Gozu and ${ }^{3}$ Ozden Basturk \\ ${ }^{1}$ Department of Fish Processing Technology, Faculty of Fisheries, \\ University of Tunceli, Tunceli, Turkey \\ ${ }^{2}$ Department of Fish Processing Technology, \\ ${ }^{3}$ Department of Basic Science, Faculty of Fisheries, University of Mersin, \\ Yenisehir Kampusu, Mersin, Turkey
}

\begin{abstract}
In this study, it is aimed to investigate the suitability of African catfish (Clarias gariepinus, B.,1822) caught intensively, especially in Mersin-Silifke for marinating and determine its shelf life. After their heads and tails were cut off and they were eviscerated first and then washed and drained of the water, the samples were put into plastic refrigerator bags and kept at $-18^{\circ} \mathrm{C}$ for 3 months. At the end of 3 months, the frozen samples were defrosted and boiled in boiling water for $5 \mathrm{~min}$. They were put in brine after cooling and preserved at $4 \pm 1^{\circ} \mathrm{C}$. In the raw material, raw protein, lipid, moisture, raw ash analyses of the samples kept frozen for 3 months and the marinated samples were done in order to monitor the changes in the food composition at 3 month intervals and Thiobarbituric Acid number (TBA), Total Volatile Basic-Nitrogen (TVB-N), peroxide number, $\mathrm{pH}$ and sensory analyses were done in order to monitor the changes in chemical quality.
\end{abstract}

Key words: African catfish, marinating, shelf life, peroxidenumber, intensively, defrosted

\section{INTRODUCTION}

The ever-increasing world population exceeded 6 billion at the turn of the new millennium while it was 2.5 billion in the $1950 \mathrm{~s}$. The increasing population both creates a shortage on agricultural food products and necessitates alternative food production. The need for animal proteins is also on the increase in parallel with famines and malnutrition in the world.

Aquaculture products which have a major role in food production are consumed in a variety of ways in the country: fresh, frozen and processed (smoked, canned, marinated, salted, dried, etc.). Consuming processed aquaculture products enables both the conservation and a more profitable usage of the product.

Marinating technology is one of the oldest known methods of food conservation and dates back to the 7th century B.C. The basic principle of marinating process is that the fish, subjected to one or more pre-processing techniques is rendered eatable by treating with acetic acid and salt. The products obtained this way are among the food items that can be consumed without any subjection to thermal treatment (Gram and Huss, 1996). Maturing process the first phase of marinating, is comprised of complex physical and chemical reactions. Marinating process takes place with the effect of neither acetic acid alone nor salt (Varlik et al., 2004). Salt and acetic acid which although have the same effect on fish meat are in fact, substances with opposite charges cancelling the effect of one another. While salt hardens the material, acetic acid softens it (Kilinc and Cakli, 2004).

In the maturing process, salt and acetic acid transfer into fish tissue continues until the salt and acetic acid levels in the fish tissue liquid are equal with the salt and acetic acid levels in the solution (Karl et al., 1994). Although, it has been reported that this transfer is completed fast, generally in two day's time (Dokuzlu, 2000 ), it may still vary depending on temperature and meat thickness.

In marinated products, it is aimed to provide the product with a longer shelf life by stopping the activities of present bacterial enzymes in the product with the effect of acetic acid and salt. Acetic acid and salt along with the enzymes from fish have an effect on the protein and lipid contents of fish although they cause destruction to a certain extent in the protein and lipid contents of fish and as a result, aromatic and delicious products are created (Schenderyuk and Byokowsky, 1990). In this study, it is aimed to achieve product diversity and improve the quality of African catfish which has a problem of

Corresponding Author: Gulderen Kurt Kaya, Department of Fish Processing Technology, Faculty of Fisheries, University of Tunceli, Tunceli, Turkey 
marketing in the country and investigate how African catfish can be integrated into economy to the benefit of fishing industry in the area.

\section{MATERIALS AND METHODS}

In the study, $40 \mathrm{~kg}$ of African catfish (Clarias gariepinus) caught from Goksu Delta were used. The cleaned and skinned fish were washed with potable tap water. After their water was drained, they were put into plastic refrigerator bags and kept at $-18^{\circ} \mathrm{C}$ for 3 months. The frozen samples were defrosted at $+4^{\circ} \mathrm{C}$ one day before the marinating process and then were put as a whole into boiling water and kept there for $5 \mathrm{~min}$.

The boiled fish meat were placed at a rate of $1: 1.5$ (fish: solution ratio) in 3 plastic cans of $10 \mathrm{~L}$ which contained brine with $3 \%$ of acetic acid and $8 \%$ of sodium chloride and the plastic cans were sealed and stored in refrigerator conditions $\left(4 \pm 1^{\circ} \mathrm{C}\right)$.

In order to determine the shelf life of the samples, the following monthly analyses were done on the fish samples stored in a cold place for 3 months and the samples after the marinating.

For chemical composition analyses: James (1995) for protein; Bligh and Dyer (1959) for lipid; Ludorff and Meyer (1973) for moisture and Mattissek et al. (1988) were used for ash analyses.

For monitoring chemical quality changes: Tarladgis et al. (1960) for Thiobarbituric Acid number (TBA) analysis; Antonacopoulos and Vyncke (1989) for Total Volatile Basic-Nitrogen (TVB-N) analysis and for peroxide (AOAS, 1994) and Hanna HI 991001 brand pH metre for
$\mathrm{pH}$ analyses were used (Ludorff and Meyer, 1973). The evaluation of sensory analyses was done according to the calculating table developed by Amerine et al. (1965). In this table, $10-7 / 0$ points are regarded as very good, 6.9-4.0 points as good and 3.9-1.0 points as decayed.

\section{RESULTS AND DISCUSSION}

The changes in nutritional and chemical quality parameters in African catfish (Clarias gariepinus) fillet in the material kept frozen for 3 months and in the marinated products during storage period were examined and the results are shown in Table 1 and 2.

Ersoy and Yilmaz (2003) determined in their study that moisture rate in raw African catfish was $73.20 \%$, raw protein $21.22 \%$, raw lipid $4.6 \%$ and raw ash $1.10 \%$. In their study on the effects of cooking methods on the mineral and vitamin contents of the products, Ersoy and Ozeren (2009) determined that raw protein in the raw African catfish material was $16.2 \%$, moisture $76.8 \%$, raw lipid $5.02 \%$ and raw ash $0.83 \%$.

Chomnawang et al. (2007) determined the raw protein, raw lipid, moisture and raw ash rates of hybrid cat fish (Clarias macrocephalus $\mathrm{x}$ Clarias gariepinus) at the beginning of storage period as $18.68,3.03,75.68$ and $1.17 \%$, respectively. It was determined that the nutritional values of African catfish raw material obtained in the study are compatible with literature data. It was observed that while the TVB-N value of fresh African catfish used for marinating was determined to be $17.15 \mathrm{mg} / 100 \mathrm{~g}$, it dropped to $11.62 \mathrm{mg} / 100 \mathrm{~g}$ at the end of 3 months of storage period. The TVB-N value recorded to be

Table 1: The changes in the nutritional composition of raw material, frozen fillet and marinated products during storage period

\begin{tabular}{|c|c|c|c|c|}
\hline \multirow[b]{2}{*}{ Storage of time } & Protein & Lipid & Moisture & Ash \\
\hline & \multicolumn{4}{|c|}{ 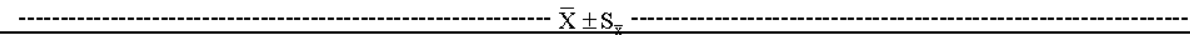 } \\
\hline Raw material & $16.42 \pm 1.45$ & $4.93 \pm 0.12$ & $73.37 \pm 0.46$ & $1.15 \pm 0.02$ \\
\hline Frozen fillet & $16.02 \pm 0.08$ & $4.52 \pm 0.04$ & $75.27 \pm 2.55$ & $4.15 \pm 0.02$ \\
\hline Day 0 (after marinating) & $19.01 \pm 0.88$ & $3.30 \pm 0.06$ & $75.63 \pm 0.23$ & $5.72 \pm 0.03$ \\
\hline Day 30 & $19.37 \pm 0.53$ & $3.67 \pm 0.06$ & $71.40 \pm 0.10$ & $5.66 \pm 0.01$ \\
\hline Day 60 & $18.04 \pm 1.69$ & $3.72 \pm 0.10$ & $71.30 \pm 0.30$ & $5.82 \pm 0.06$ \\
\hline Day 90 & $19.03 \pm 0.02$ & $3.86 \pm 0.04$ & $72.83 \pm 0.45$ & $6.17 \pm 0.31$ \\
\hline Day 120 & $20.35 \pm 0.05$ & $3.48 \pm 0.08$ & $74.57 \pm 0.81$ & $5.82 \pm 0.12$ \\
\hline Day 150 & $20.19 \pm 0.85$ & $4.15 \pm 0.05$ & $71.70 \pm 0.82$ & $5.74 \pm 0.27$ \\
\hline
\end{tabular}

Table 2: The changes in the chemical quality parameters of raw material, frozen fillet and marinated products during storage period

\begin{tabular}{|c|c|c|c|c|c|}
\hline \multirow[b]{2}{*}{ Storage of time } & TVB-N (mg/100g) & $\mathrm{TBA}\left(\mathrm{mg} \mathrm{MA} \mathrm{kg}{ }^{-1}\right)$ & POS (meq kg ${ }^{-1}$ ) & $\mathrm{pH}$ & Sensory \\
\hline & \multicolumn{5}{|c|}{ - } \\
\hline Ham materyal & $17.15 \pm 0.81$ & $1.23 \pm 0.48$ & $1.78 \pm 0.08$ & $6.11 \pm 0.03$ & * \\
\hline Raw material & $11.62 \pm 0.91$ & $1.64 \pm 0.11$ & $2.10 \pm 0.05$ & $4.35 \pm 0.04$ & * \\
\hline Frozen fillet & $11.07 \pm 0.11$ & $2.54 \pm 0.08$ & $2.22 \pm 0.11$ & $3.80 \pm 0.00$ & $4.47 \pm 0.50$ \\
\hline Day 0 (after marinating) & $12.53 \pm 0.05$ & $3.34 \pm 0.06$ & $2.47 \pm 1.04$ & $3.95 \pm 0.01$ & $4.37 \pm 0.32$ \\
\hline Day 30 & $12.83 \pm 0.46$ & $2.42 \pm 0.23$ & $2.61 \pm 0.15$ & $4.09 \pm 0.02$ & $2.50 \pm 0.10$ \\
\hline Day 60 & $12.11 \pm 0.82$ & $3.38 \pm 0.08$ & $2.88 \pm 0.04$ & $4.14 \pm 0.03$ & $2.20 \pm 0.00$ \\
\hline Day 90 & $14.90 \pm 0.80$ & $3.68 \pm 0.42$ & $3.26 \pm 0.03$ & $4.17 \pm 0.01$ & $1.00 \pm 0.00$ \\
\hline Day 120 & $17.23 \pm 0.79$ & $4.18 \pm 0.19$ & $3.57 \pm 0.06$ & $4.24 \pm 0.02$ & $1.00 \pm 0.00$ \\
\hline
\end{tabular}


$11.07 \mathrm{mg} / 100 \mathrm{~g}$ on the day 0 when the marinades matured, increased continuously during the storage period and reached $17.23 \mathrm{mg} / 100 \mathrm{~g}$. It was determined as a result of the analyses that the TVB-N value in marinades was $<32-36 \mathrm{mg} / 100 \mathrm{~g}$ limit value Varlik et al. (2000) and Ludorff and Meyer (1973) defined for fresh water fish and that the TVB-N value of the defrosted samples after freezing was $<25 \mathrm{mg} / 100 \mathrm{~g}$ limit value defined by the same researchers for trout stored in a cold place.

It was determined that the TVB-N value found to be $17.15 \mathrm{mg} / 100 \mathrm{~g}$ in the study for raw material was higher than the value (Ersoy and Yilmaz, 2003) defined as $14 \mathrm{mg} / 100 \mathrm{~g}$ for African catfish raw material. Olgunoglu (2007) reported in his study on anchovy marinades that the TVB-N value which was $11.90 \mathrm{mg} / 100 \mathrm{~g}$ at the beginning of storage period, reached a value of $16.91 \mathrm{mg} / 100 \mathrm{~g}$ at the end of a 7 month storage period.

Aksu et al. (1997) reported that the TVB-N value $8.3 \mathrm{mg} / 100 \mathrm{~g}$ in marinated anchovy (Engraulis encrasicolus) reached $15.2 \mathrm{mg} / 100 \mathrm{~g}$ at the end of a 150 days storage period and Dokuzlu (2000) reported that the TVB-N value $9.8 \mathrm{mg} / 100 \mathrm{~g}$ in marinated anchovy reached $14 \mathrm{mg} / 100 \mathrm{~g}$ at the end of a 8 month storage period at $+4^{\circ} \mathrm{C}$. Ozden and Baygar (2003) reported in their study in which they investigated the effects of different packaging methods on the quality criteria of marinated fish that the TVB-N values of anchovy (Engraulis encrasicolus), scad (Trachurus trachurus) chub mackerel (Scomber japonicas) and sardine (Sardina pilchardus) recorded up to the day 120 were considerably below the edible limit values although increases in TVB-N during storage periods varied. In another study by Varlik et al. (2004) it was reported that the TVB-N value of fish balls on the 150 th day was $10.45 \mathrm{mg} / 100 \mathrm{~g}$.

In the study, the TBA values were found to be $1.23 \mathrm{mg} \mathrm{MA} \mathrm{kg}^{-1}$ for raw material used to make products and $2.54 \mathrm{mg} \mathrm{MA} \mathrm{kg}^{-1}$ at the beginning of storage and $4.18 \mathrm{mg} \mathrm{MA} \mathrm{kg}^{-1}$ at the end of storage for the marinated African catfish.

In his study, he investigated some quality changes in anchovy (Engraulis encrasicolus) marinades prepared by using two different maturing solutions (group 1:10\% salt $+2 \%$ vinegar, group $2: 15 \%$ salt $+2 \%$ vinegar $)$, Yapar (1998) reported that while the TBA value was $1.65 \mathrm{mg} \mathrm{MA} \mathrm{kg}$ in the 1 st week in group 1 , it increased to $2.35 \mathrm{mg} \mathrm{MA} \mathrm{kg}{ }^{-1}$ in the 10 th week and it varied between 1.13 and $2.34 \mathrm{mg} \mathrm{MA} \mathrm{kg}^{-1}$ in group 2 . Sallam et al. (2007) found the raw TBA value of pacific saury (Cololabis saira) which they marinated in different acid solutions to be $0.37 \mathrm{mg} \mathrm{MA} \mathrm{kg}{ }^{-1}$ and emphasized that marinades were of good quality, although no steady increase had happened during the 90 days of storage period. Olgunoglu (2007) found out that the TBA value of anchovy (Engraulis encrasicolus) marinades at the beginning of storage period was $1.16 \mathrm{mg} \mathrm{MA} \mathrm{kg}^{-1}$ and it steadily increased and reached $4.20 \mathrm{mg} \mathrm{MA} \mathrm{kg}^{-1}$ at the end of 7 months of storage period maintained that the TBA number should not be $<3$ in a very good material and it should not be $>5$ in a good material.

When all the TBA values obtained throughout the study are taken into consideration, it was determined that TBA values increased as the storage period came to an end but still, marinades were within the limits of a good quality marinade at the end of a 150 days storage period. Varlik et al. (2004) reported that the peroxide number of an aquaculture product that could be defined as of good quality should be between 2 and 5 milimol $\mathrm{O}_{2} \mathrm{~kg}^{-1}$ in fat. The peroxide number of the prepared marinades calculated until the end of the 150 days of storage period showed that African catfish marinades were of good quality.

While Ersoy and Yilmaz (2003) calculated the $\mathrm{pH}$ value in raw African catfish material as 6.67 and Chomnawang et al. (2007) as 6.41, Suvanich and Marshall (1998) stated that the $\mathrm{pH}$ value in fish after rigor mortis was between 6.2 and 6.5 . It was observed that the $\mathrm{pH}$ values of the raw material recorded in the study are in accordance with those obtained by the researchers. It was determined that the $\mathrm{pH}$ values of the marinated products calculated throughout the storage period show similarity with the values 4.0-4.5. Varlik et al. (2004) defined for good quality marinated products (Suvanich and Marshall, 1998). According to the sensory analyses of marinated African catfish fillets, it was determined that they were marketable up to the 30th day and decayed after the 60th day.

\section{CONCLUSION}

As a result of the analyses, it was determined that no nutritional loss happened in the marinated products. In the light of data obtained from the analyses of the chemical quality parameters, it was concluded that although African catfish marinades were of good quality, it was not acceptable sensorily. It is thought that it will be beneficial to carry out studies on sensorily different methods of marinating in the future.

\section{REFERENCES}

AOAS., 1994. Official Methods and Recommended Practices of the American Oil Chemists Society. American Oil Chemists Society, Champaign. 
Aksu, H., N. Erkan, H. Colak, C. Varlik, N. Gokoglu and M. Ugur, 1997. Some changes in anchovy marinades during production in different acid-salt concentrations and determination of shelf life. J. Fac. Vet. Med., 8: 86-90.

Amerine, M.A., R.M. Pangbnor and E.B. Roseller, 1965. Principles of Sensory Evaluation of Food. Academic Press, New York and London, pp: 16-69.

Antonacopoulos, N. and W. Vyncke, 1989. Determination of volatile basic nitrogen in fish: A third collaborative study by the West European Fish Technologists Association (WEFTA). Zeitschrift Fur Lebensmittel Untersuchung Und Forschung, 189: 309-316.

Bligh, E.G. and W.J. Dyer, 1959. Rapid method of total lipit extraction and purification. Can. J. Biochem. Physiol, 37: 911-917.

Chomnawang, C., K. Nantachai, J. Yongsawatdigul, S. Thawornchinsombut and S. Tungkawachara, 2007. Chemical and biochemical changes of hybrid catfish fillet stored at $4 \mathrm{oC}$ and its gel properties. Food Chem., 103: 420-427.

Dokuzlu, C., 2000. Shelf-life of the marinated local anchovies. J. Fac. Vet. Med., 19: 45-49.

Ersoy, B. and A. Ozeren, 2009. The effect of cooking methods on mineral and vitamin contents of African catfish. Food Chem., 115: 419-422.

Ersoy, B. and B.A. Yilmaz, 2003. Frozen storage of African catfish (Clarias gariepinus Burchell, 1822) mince balls. Turk. J. Vet.Anim. Sci., 27: 827-832.

Gram, L. and H.H. Huss, 1996. Microbiological spoilage of fish and fish products. Int. J. Food Microbiol., 33: $121-137$.

James, C.S., 1995. Analytical Chemistry of Foods. 1st Edn., Chapman and Hall, New York.

Kilinc, B. and S. Cakli, 2004. Marination technology. E.U. Fish. J., 21: 153-156.

Karl, H., A. Roepstorff, H.H. Huss and B. Bloemsma, 1994. Survival of Anisakis larvae in marinated herring fillets. Int. Food Sci. Technol., 29: 661-670.

Ludorff, W. and V. Meyer, 1973. Fische und Fisherzeugnisse. Verlag Paul Parey, Berlin, Hamburg, pp: 209-210.
Mattissek, R., F.M. Shengel and G. Steiner, 1988. Lebensmittel-Analytick. Springer Verlag, Berlin, Tokyo, pp: 440.

Olgunoglu, I.A., 2007. Sensory chemical and microbiological changes of marinated anchovy (Engraulis Engrasicholus L., 1758). Ph.D. Thesis, Institute of Natural and Applied Sciences University of Cukurova. pp: 111.

Ozden, O. and T. Baygar, 2003. The effect of different packaging methods on some quality criteria of marinated fish. Turk. J. Vet. Anim. Sci., 27: 899-906.

Sallam, K.I., A.M. Ahmed, M.M. Elgazzar and E.A. Eldaly, 2007. Chemical quality and sensory attributes of marinated pacific saury (Cololabis saira) during vacuum-packaged storage at $4^{\circ} \mathrm{C}$. Food Chem., 102: 1061-1070.

Schenderyuk, V. and P.J. Byokowsky, 1990. Salting and Marinating of Fish. Chapter 9. In: Seafood: Recources, Nutritional Composition and Preservation, Sikorski, Z.E. (Ed.). CRS Press. Inc., Boca Raton, Florida, pp: 147-162.

Suvanich, V. and D.L. Marshall, 1998. Influence of storage time and temperature on quality of catfish (Ictalurus punctatus) frames. J. Aquatic Food Prod. Technol., 7: 61-76.

Tarladgis, B.G., B.M. Watts, M.T. Younathan and L. Dugan, 1960. A distilation method for the quantitative determination of malonaldehyde in rancid foods. J. Am. Oil Chem. Soc., 37: 44-48.

Varlik, C., N. Erkan, O. Ozden, S. Mol and T. Baygar, 2004. Sea Food Processing Technology. University of Istanbul, Faculty of Fisheries, Fish Processing Technolog 7, Istanbul, pp: 491.

Varlik, C., N. Erkan, S. Metin, T. Baygar and O. Ozden, 2000. Determination of the shelf-life of marinated fish balls. Turk. J. Vet. Anim. Sci., 24: 593-597.

Yapar, A., 1998. Some quality changes in anchovy (Engraulis encrasicolus) marinades produced by using 2 different ripening solution. Turk. Fish., 15: $1-7$. 